\title{
Promoting the autonomy of rural older adults in active aging
}

\author{
Promoção da autonomia de idosos rurais no envelhecimento ativo
}

Promoción de la autonomía de los ancianos rurales en el envejecimiento activo

\begin{abstract}
Celmira Lange', Ivonete Teresinha Schülter Buss Heidemann", Denise Somavila Przylynski Castro', Andressa Hoffmann Pinto', Carla Weber Peters', Michelle Kuntz Durand"

' Universidade Federal de Pelotas. Pelotas, Rio Grande do Sul, Brazil.

" Universidade Federal de Santa Catarina. Florianópolis, Santa Catarina, Brazil.

How to cite this article:

Lange C, Heidemann ITSB, Castro DSP, Pinto AH, Peters CW, Durand MK. Promoting the autonomy of rural older adults in active aging. Rev Bras Enferm [Internet]. 2018;71(5):2411-7. DOI: http://dx.doi.org/10.1590/0034-7167-2017-0570
\end{abstract}

Submission: 08-10-2017 Approval: 02-07-2018

\begin{abstract}
Objective: to understand how the rural older adults promote their autonomy in active aging. Method: qualitative research through the Paulo Freire's research itinerary, consisting of three steps: area of research; encoding and decoding; and critical unveiling. Seventeen older adults living in the rural area of a municipality in Southern Brazil participated in the research. Six culture circles were conducted from July to December 2016. Results: the investigation revealed two generating themes: joint pain and participation in groups. The understanding of autonomy promotion for the active aging of older adults is focused on the physical capacity and independence of activities of daily living. Final considerations: the culture circles have promoted reflection moments for the participants, especially about the advantages and difficulties related to the practice of autonomy in the exercise of citizenship for active aging in the rural area. Descriptors: Personal Autonomy; Older Adult; Health Services for Older Adults; Health Promotion; Rural Population.
\end{abstract}

\section{RESUMO}

Objetivo: compreender como os idosos rurais promovem sua autonomia no envelhecimento ativo. Método: pesquisa de abordagem qualitativa por meio do itinerário de pesquisa de Paulo Freire, que consiste em três etapas: investigação temática; codificação e descodificação; e desvelamento crítico. Participaram da pesquisa dezessete idosos residentes na zona rural de um município do sul do Brasil. Foram realizados seis círculos de cultura de julho a dezembro de 2016. Resultados: a investigação revelou dois temas geradores: dores articulares e participação em grupos. Descobriu-se também que a compreensão sobre a promoção da autonomia para o envelhecimento ativo dos idosos está voltada para a capacidade física e a independência para as atividades cotidianas. Considerações finais: os círculos de cultura promoveram espaços de reflexão dos participantes, especialmente sobre as facilidades e as dificuldades relacionadas à prática de autonomia no exercício da cidadania para um envelhecimento ativo na área rural.

Descritores: Autonomia Pessoal; Idoso; Serviços de Saúde para Idosos; Promoção da Saúde; População Rural.

\section{RESUMEN}

Objetivo: comprender como los ancianos rurales promocionan su autonomía en el envejecimiento activo. Método: investigación de abordaje cualitativo por medio del itinerario de investigación de Paulo Freire, que consiste en tres etapas: la investigación temática; la codificación y la descodificación; y el desvelamiento crítico. Participaron de la investigación diecisiete ancianos residentes en la zona rural de un municipio del sur de Brasil. Fueron realizados seis círculos de cultura de julio a diciembre de 2016. Resultados: la investigación reveló dos temas generadores: los dolores articulares y la participación en grupos. Se descubrió también que la comprensión sobre la promoción de la autonomía para el envejecimiento activo de los ancianos está destinada para la capacidad física y la independencia para las actividades cotidianas. Consideraciones finales: los círculos de cultura promocionaron espacios de reflejo de los participantes, especialmente sobre las facilidades y las dificultades relacionadas a la práctica de autonomía en el ejercicio de la ciudadanía para un envejecimiento activo en el área rural.

Descriptores: Autonomía Personal; Anciano; Servicios de Salud para Ancianos; Promoción da Salud; Población Rural. 


\section{INTRODUCTION}

Autonomy is a core value in the characterization of health, thus collaborative/interactive learning emerges as a promoter of knowledge, enabling the production of freedom ${ }^{(1)}$. Therefore, autonomy, as freedom in the action based on the awareness of our interdependence as human beings, is strengthened when individuals start to change the environments created, initially assisted, and then by themselves, reproducing and sharing with others the knowledge to build different learning processes.

Promoting user independence is of paramount importance for them to be co-responsible for the determinants of their healthdisease process. Among the important tools to promote their autonomy, it is essential to encourage them to co-participate in the care of their health, that is, learn to take care of themselves and make relevant decisions on their actions in the process of living ${ }^{(2)}$.

Autonomy is marked by the right to diversity, free speech and freedom of behavior of individuals and groups, as long as the limits of damage to third parties are respected. In a democracy, autonomy is relative because of different social groups that enjoy different degrees of autonomy, which highlights its political dimension, since it is a consequence of power relations ${ }^{(3)}$.

The impact of aging on the Brazilian society has made the authorities approve laws aimed at active and healthy aging. One of them is the National Health Promotion Policy, which has autonomy as one of the principles, referring to the identification of potentialities and development of capabilities, enabling the conscious choices of subjects and communities on their actions and trajectories ${ }^{(4)}$.

The term "active aging" was adopted by the World Health Organization in the late 1990s and is related to the biopsychosocial balance and to the ability older adults have in developing their potential. Active aging assumes a healthy, successful, satisfying, productive position and, depending on the context, presents itself as a new paradigm about aging and old age ${ }^{(5)}$.

IBGE data indicate that older adults are $14.3 \%$ of the Brazilian population. The state of Rio de Janeiro comes first, with $17.4 \%$ of the older population(6), and the state of Rio Grande do Sul, with $17.3 \%$, is the second state with the highest proportion of older adults. In this context, the aging process becomes a challenge for the 21 st century, especially with regard to aging in a healthy way, maintaining independence and autonomy.

Thus, the strategies for promoting autonomy for an active aging with rural seniors are possibilities that allow changes in the quality of life of this population, with the exercise of citizenship and the strengthening of the Unified Health System (SUS). The study analysis ${ }^{(7)}$ points out the lack of original research on the subject, which is relevant due to the current scenario in Brazil. The life expectancy of the older population has increased and, therefore, needs qualified professionals to deal with this new reality, including the older adult with autonomy, in a full and ethical way. Accordingly, this study can contribute to the reflection and change of practice of health professionals, fostering discussions that address aspects of the older adults' autonomy in society. Thus, the following question is considered: how can older adults from a rural area of Southern Brazil promote their autonomy?
In accordance with the principles of SUS, it is essential to promote autonomy in the active aging process of the older adult, from the users' point of view, encouraging them to practice solidarity with intersectoral knowledge.

\section{OBJECTIVE}

To understand how the older population from a rural municipality in the south of Brazil understands their autonomy in active aging.

\section{METHOD}

\section{Ethical aspects}

This research was approved by the Research Ethics Committee of the Medical School of the Federal University of Pelotas. The informed consent form (ICF) was signed by seventeen seniors who participated in the research. To ensure anonymity, the participants were identified as I1, I2, and so on, until I17.

\section{Theoretical-methodological framework and type of study}

This is a descriptive study with a qualitative approach. As a methodological framework, Paulo Freire's research itinerary was used, which consists of three dialectical and intertwined moments: area of research; encoding and decoding; and critical unveiling through the culture circle. We used the concepts of health promotion and autonomy as theoretical framework for the critical unveiling of the themes in the culture $\operatorname{circles}^{(8)}$.

\section{Methodological procedures}

\section{Study scenario}

The municipality studied has 343,651 inhabitants, while the rural area has 22,082 inhabitants, among which $16.7 \%$ are aged 60 years or more ${ }^{(6)}$. The study was conducted with seniors enrolled in Brazil's Family Health Strategy and residents of the rural municipality, located in the extreme south of Brazil. The authors had already conducted other research in the region, titled "Prevalence and factors associated with frailty in an older population," resulting in an article about the functional capacity of older adults ${ }^{(9)}$. The health unit where the research was conducted has 426 older adults registered. This unit also maintains groups of seniors, hypertensive, diabetic and obese people, alcoholics and smokers, as well as mental health groups, training group for pregnant women, school work, among others, whose meetings take place fortnightly or monthly.

\section{Data source}

Paulo Freire's research itinerary was conducted in a group with seventeen older people who participate in a voluntary basis in the meeting "Senior Dance" held every two weeks. The senior dance group is conducted by a community health agent qualified for this activity. It was agreed with the older adults that they would give up one hour of each meeting for the culture circles, developed in the period from July to December 2016.

\section{Data collection and organization}

Paulo Freire's research itinerary was used as data collection, outlining the research and the analysis of themes. The method proved to be suitable for the research purpose. 
The itinerary includes: (1) the investigation of generating themes, (2) encoding and decoding and (3) the critical unveiling. Figure 1 presents the steps of this method, suggested by Heidemann, Wosny, Boehs ${ }^{(10)}$.

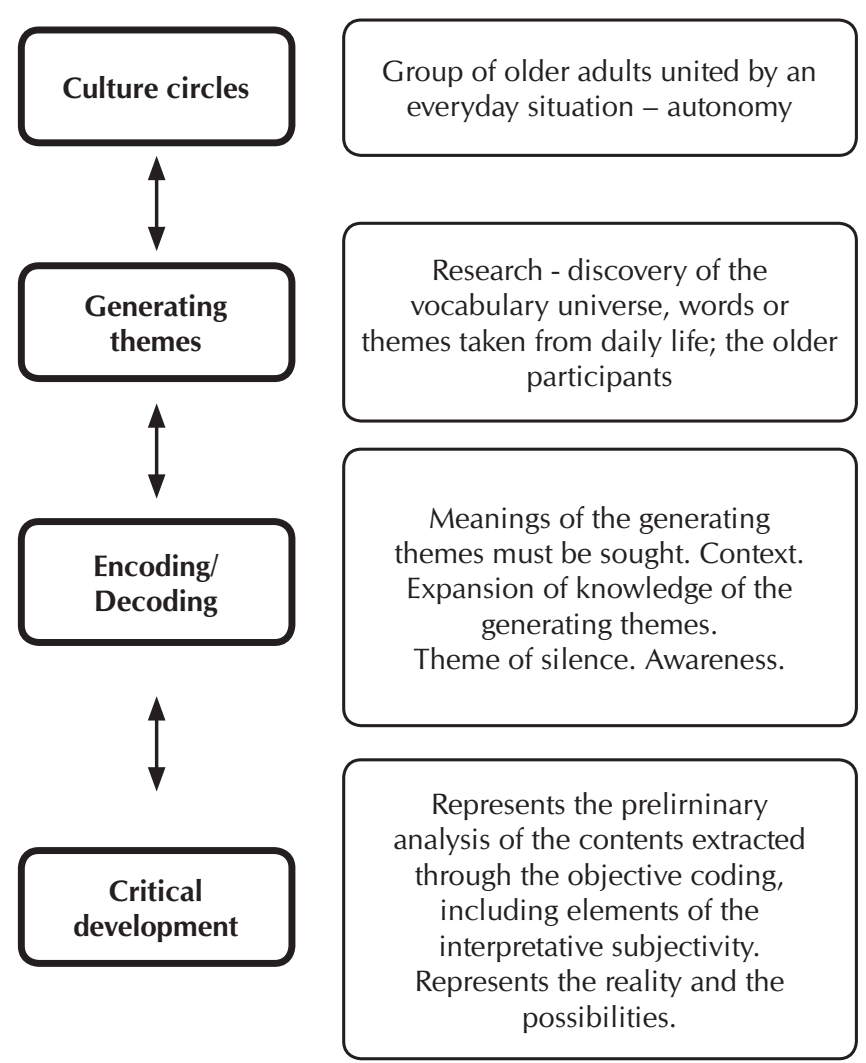

Figure 1 - Steps of Paulo Freire's research itinerary

This method enables the dialogue between the researcher and the subjects ${ }^{(10)}$, allowing the participants' reflections to take them to new action proposals on daily life and autonomy promotion for active aging. The steps proposed are developed within the "culture circles" - term coined by Freire -, composed of a dynamic environment to learn and exchange knowledge.

The entry in the field occurred after a visit to the health team and to some groups composed of users of the UBS (Unidade Básica de Saúde - Basic Health Unit) to disclose the objectives of the research and clarify Freire's research itinerary. The visits occurred in three dialectic moments ${ }^{(8,10)}$ distributed into six meetings of culture circles, according to the method steps: research of the generating themes; encoding and decoding; and critical unveiling.

For the development of culture circles we obtained the aid of two nursing students; while one person took notes in the field journal, another, with a video camera and audio recorder, recorded the information in full, procedure previously authorized by the participants. The research in the culture circles was based on some guide questions that fostered reflections by the participants, thus generating themes that were registered with colorful marker in a wall-mounted panel, with big letters, so that everyone could read.
The unveiling of the themes was held with all participants involved in the research, as suggested by Paulo Freire's research itinerary. To that end, we analyzed the themes and thoughts that had been highlighted in the culture circles. Synthetic frames highlighting health promotion activities that provided autonomy for the older adults in active aging were developed.

\section{RESULTS}

The older participants of culture circles were aged between 60 and 81 years, an average of 70 years. Of the seventeen participants, thirteen were women. Schooling (years at school) ranged from one to six years, with an average of 3.3 years. Only one older woman did not have the retirement benefit and nine continued working in agriculture.

As for the reporting of diseases with medical diagnosis, all had some disease, with high blood pressure being reported by fourteen older people. The average of diseases per older adult remained at two. All participants were receiving medical treatment, ranging from one to nine medications a day, an average of 3.7 medications a day per older adult. Regarding the participation in groups, an older adult attended six different groups and several older adults participated in other groups developed at the UBS and/or in different religious denominations.

The guide questions thrown in the first culture circle were: what are the healthcare services that promote active aging? How do you take care of your life and health, inside and outside the house? What is autonomy? What are the advantages and difficulties of being autonomous? The themes that emerged from the guide questions were related to the reality of the older adult, especially those concerning the advantages and difficulties faced in daily life, being found fourteen advantages and eight difficulties. The themes were encoded and decoded in two to be unveiled in the culture circles.

In the second culture circle, 22 generating themes related to the reality of the participants were selected and investigated. The themes listed expressed what the older adults experienced at the moment, and we observed that autonomy, for the group studied, is closely related to mobility, which can be observed in the following utterances:

What I can do on my own, not depending on others. (I5)

I think I have autonomy when I can leave and come back home. (17)

To me if you come here you have autonomy. (19)

In the third culture circle, in the coding stage, the 22 generating themes announced in the second meeting were resumed. The themes were encoded and decoded in the culture circle and, from that, two significant themes were selected to be worked in the unveiling step. (1) joint pain, as a difficulty for the exercise of autonomy in aging; (2) participation in groups, especially in the senior dance, favoring the autonomy in old age. For each theme a culture circle was conducted in order to deepen the debate and the experience of the participants. Among the themes developed, the difficulties and advantages 
to maintain autonomy stood out, the former being strongly influenced by the conformation of the rural area, unpaved roads, the lack of public transport, and by the distance between the homes and the services. Thus, for the group, to be capable of moving is synonymous with being autonomous. In the second theme - advantages - it is clear the importance of the senior dance, because the development of this activity goes beyond a physical practice for the older adults, since it provides moments of immeasurable exchanges on life matters.

Joint pain/arthritis was one of the decoded themes and, based on that, the critical development of the participants was instigated. To this end, the older adults indicated, through statements, the need for theoretical background in the fourth culture circle. This theme was relevant after qualifying the knowledge in order to empower decision-making, because two older adults had an indication to undergo hip replacement surgery and other seniors had family members who had undergone the surgery. The utterances indicate:

The problem is the pain, it begins to harden the leg and pull all these nerves up here. (I5)

I'm using the second hip replacement and now I'm going to get a third prosthesis, but the problem is that it's too expensive [the surgery]. (I9)

The critical unveiling of the themes was held during the culture circles. The themes were reflected upon and discussed based on the experiences of the older adults' everyday life.

In the fourth culture circle, the critical unveiling of the theme "joint pain" occurred, highlighted by the participants as pain in the upper limbs, but mainly in the lower limbs, as an important limitation to the exercise of autonomy.

I also think that if I had healthy legs, with all the help, I could get around and wouldn't need to depend on anyone, that helps a lot. (17)

In this circle, participants contributed to the debate by raising questions related to the surgery and the need for hip prosthesis, the function of the prosthesis, which precautions need to be taken, how to avoid the wear and tear of the bone and the use of collagen. For participants, aging with health and without prosthesis starts in the young adulthood.

To keep me healthy, I have to start early, so I can do it by my own free will. (I6)

Now I have more knowledge to make a decision about surgery. (I16)

In the fifth culture circle, the theme "senior dance" was unveiled as one of the relevant groups in which the older adults participate and promote their autonomy. From the participants standpoint, the senior dance collaborates with the autonomy of the older adult, as it helps in memory, concentration, orientation, interpersonal relationships, integration, exercise/movement, objective/reason to leave the house and social experiences with the group.
Our minds are getting better, just by coming here and not being at home. (I1)

Plus, it prevents falls, improves sleep, assists in agility, balance, improves domestic activities, we can move and do everything by ourselves. (113)

Fun, it improves blood circulation, provides muscle relaxation, reduces joint pain, helps with the spine (pain), legs and shoulders. (I5)

In the sixth culture circle, a joint evaluation of the experience and the closure of the research were conducted. The participants considered that there was an exchange of experiences, friendship, personal benefits, relaxation and learning during the meetings. The older adults reported:

My husband came in with high blood pressure and left without it. (17)

It was very good, brought us personal benefits, made us think about our importance, made us feel useful, review the importance of older people in society, it explained subjects from our daily life, there was relaxation, friendship, and exchange of experience. (I8)

It was important to participate in local community interests, to give opinion on decisions that mattered to the health team, which I find very good. (19)

The dialogues shared in the culture circles between the participants and the researcher created a learning/empowerment space, aiming at the understanding of the older adults about the autonomy for active aging.

\section{DISCUSSION}

The themes were identified through a written display on a panel, where each person expressed her/his understanding of autonomy, emphasizing some advantages and difficulties in the everyday life. However, we realized the difficulty in understanding the concept clearly.

Their understanding of autonomy is focused on physical ability and independence for everyday activities. However, the definition goes beyond physical capacity: it covers the ability to control, deal and deliberate on how to live daily life, following personal rules and preferences. Autonomy is considered by means of two conditions: freedom and action. Freedom is related to the independence of the control of influences, and action deals with the ability to act with intention. An autonomous older person acts according to a plan, but an older person with diminished autonomy shall be controlled or unable to act deliberately ${ }^{(11)}$.

The decision-making process of the older adults was also present in the reports. The culture circles assisted in the identification of potentialities and in the development of capacities, enabling conscious choices and trajectories for the autonomy of older adults, since this type of activity allows participants to have the necessary understanding to practice their own independence 
vis-à-vis the health condition presented, emphasizing the relevance of empirical knowledge and empowerment ${ }^{(12)}$.

The participation of older adults in groups organized by the Family Health Strategy team allows them to promote a political consciousness in order to trigger autonomy towards active aging. When looking at the participants' characterization, it is evident they are active and functionally independent. Research also shows that, even retired, the older adults remain participating in groups and performing activities in agriculture, in addition to religious and household chores and leisure activities, which implies a socio-familiar inclusion that can make the difference in functional capacity and active aging. A study carried out in Paraiba reveals similar data, in which $100 \%$ of the older respondents had functional independence, even among those who did not exercise but were still active in domestic and religious activities ${ }^{(13)}$.

Regarding schooling, we observed that all of them were literate, but they have not completed elementary school, which is probably due to the difficulties of access to education that existed a few decades ago. The fact that all were literate may have a cultural and regional influence. A study conducted in Southern Rio Grande do Sul with rural seniors that attended school between the decades of 1920 and 1940 reported that there were many difficulties of access to schools in rural areas, and the few educational institutions that existed nearby consisted of five years of schooling. Despite all the difficulties, such as distance, lack of school and the cost of tuition of parochial schools, there was a belief in the writing culture: everyone should at least know how to read. This was essential for citizen formation ${ }^{(14)}$.

All the participants in this investigation reported receiving treatment for at least one disease, high blood pressure being the most cited one. Such datum is also found in another study ${ }^{(13)}$, in which $79 \%$ of seniors reported having some pathology, arterial hypertension being the most frequent. According to the World Health Organization ${ }^{(15)}$, the concept of health for the 21st century must be dynamic and socioeconomic - as a response of the individual to the conditions of the place where she/he lives, considering physical, mental and social health dimensions, in a broader perspective, as well as an intersectoral and interdisciplinary work to promote healthy living. Thus, we can affirm that the practices developed by the Family Health Strategy team on the community researched are important to fulfill the challenge of active aging with autonomy for the older adults living in the rural area.

Regarding musculoskeletal disorders, the participants reported concern about the joint pain, especially in the lower limbs, as an important limitation to the exercise of autonomy. Some organic changes occur in individuals during the aging process, such as mass loss and decreased muscle strength, loss of body balance, decreased bone mineral density, osteoarthritis, gradual loss of visual, hormonal changes, weight loss, dementia, among others $^{(16)}$. Therefore, the need to expand the knowledge through lectures and reflections upon the chronic-degenerative joint disease arose from the critical unveiling, emphasizing health care directed to the empowerment and autonomy of the older adults, contributing to improving the health and quality of life during the aging process.
In the accounts of the participants we noted the importance they give to the participation in group activities for autonomy in the aging process. This importance is reinforced by a study developed with a social group of older adults, who noticed an improvement in the quality of life of the older participants in the study, highlighting the practices related to socialization, entertainment, education and health, aiming at providing benefits, such as stimulus, autonomy and the consolidation of a support network with the intensification of bonds and sharing of feelings ${ }^{(17)}$. Still in regard to the benefits of social groups, another study conducted in the interior of Ceará State investigated the perception of the older adults treated in a UBS on quality of life and health promotion, becoming clear that the practice of physical activities, interaction with groups in the community and the good interpersonal relationships are fundamental strategies to increase the welfare in the old age ${ }^{(18)}$.

As to active aging, aiming at evaluating the influence of institutionalization on the autonomy and quality of life perceived among institutionalized older adults, a study ${ }^{(19)}$ had a sample of 104 older adults from three residential centers of Santander, in Spain. The results of the study showed a decline in the autonomy and independence of older adults as the time of institutionalization increased. This happened due to the lack of support and physical and social activities, decreased mobility, loneliness, depression and apathy, among other factors.

Autonomy has been built and exercised in the experience of the older adults participating in the study, especially when they claim to have freedom to choose and act in their daily life. Even older people who have weaker health need to have autonomy stimulated through actions such as active listening, considering the uniqueness of the aging process of each person and ensuring the right to exercise their autonomy ${ }^{(7)}$.

The participation in the senior dance group also enables the autonomy because it stimulates the older adult to leave the house and socialize, participate and make decisions in the community where she/he lives, for the sake of health and well-being. In a study conducted by a senior dance group in São Paulo ${ }^{(20)}$, whose goal was to evaluate the benefit of dance for 25 participants, the authors concluded that dancing brings benefits to balance, assists in activities of daily life, and stimulates autonomy.

\section{Limitation of the study}

The limitation of the study may be the number of participants and the scenario, composed of a single group of older adults from the rural area, who have their own characteristics. Even though it is a group of older people from the rural area, each group will promote the autonomy influenced by their daily life experience, which could bring different conceptions of autonomy. As a plus, we highlight the possibility of other studies on the same topic with older adults living in rural areas.

\section{Contributions to the nursing field}

Nurses, as promoters of health, need to consider the older adults' understanding of autonomy and active aging. For that, the culture circles provide a space for dialogue between professionals and seniors, which allows to know the participants in 
their entirety, enabling a better planning and development of unique health actions, as well as nursing practices to improve the quality of life.

\section{FINAL CONSIDERATIONS}

Considering the promotion of autonomy for active aging, the results of this research indicate that older adults understand that their emancipation depends on the physical ability they have to promote independence and develop the activities of daily living. In the culture circles, the participants stated two generating themes that facilitate or hinder the promotion of autonomy in active aging: senior dance and joint pain, respectively. Thus, it is important to discuss such theme with rural older adults, and Paulo Freire's research itinerary, through the culture circles, is a reflection space where participants can point out the advantages and the difficulties for the practice of autonomy and exercise of citizenship for an active aging in the rural area.

\section{REFERENCES}

1. Gaudenzi P, Ortega F. notions of autonomy and normality. Ciênc Saúde Colet[Internet]. 2016[cited 2017 Nov 22];21(10):3061-70. Available from: http://www.scielo.br/pdf/csc/v21n10/1413-8123-csc-21-10-3061.pdf

2. Baratieri T, Sangaleti CT. O enfermeiro da saúde da família e a promoção da autonomia do usuário: análise reflexiva. Rev Enferm UFPE[Internet]. 2013[cited 2017 Mar 6];7(12):6921-28. Available from: http://www.revista.ufpe.br/revistaenfermagem/index.php/ revista/article/view/4039

3. Haeser ML, Büchele F, Brzozowski FS. Considerações sobre a autonomia e a promoção da saúde. Physis[Internet]. 2012 [cited 2017 Mar 25];22(2):605-20. Available from: http://www.scielo.br/pdf/physis/v22n2/11.pdf

4. Rocha DG, Alexandre VP, Marcelo VC, Rezende R, Nogueira JD, Sá RF. Processo de revisão da Política Nacional de Promoção da Saúde: múltiplos movimentos simultâneos. Ciênc Saúde Colet[Internet]. 2014[cited 2017 Feb 27];19(11):4313-22. Available from: http://www.scielosp.org/pdf/csc/v19n11/1413-8123-csc-19-11-4313.pdf

5. Bidel RMR, Tomicki C, Pichler NA, Portella MR. Envelhecimento ativo na concepção de um grupo de enfermeiros. Rev Kairós[Internet]. 2016[cited 2017 Jan 28];19(22):207-25. Available from: https://revistas.pucsp.br/index.php/kairos/article/view/32627

6. Brasil. Instituto Brasileiro de Geografia e Estatística-IBGE. Síntese de Indicadores Sociais (SIS):uma análise das condições de vida da população brasileira[Internet]. 2016[cited 2017 May 26]. Available from: http://www.ibge.gov.br/home/estatistica/pesquisas/ pesquisa_resultados.php?id_pesquisa $=47$

7. Cunha JXP, Oliveira JB, Nery VAS, Senae LS, Boery RNSO, Yarid SD. Autonomia do idoso e suas implicações éticas na assistência de enfermagem. Saúde Debate[Internet]. 2012[cited 2017 May 20];35(95):657-64. Available from: http://www.scielo.br/pdf/sdeb/ v36n95/a18v36n95.pdf

8. Heidemann ITSB, Dalmolin IS, Rumor PCF, Cypriano CC, Costa MFBNA, Durand, MK. Reflexiones sobre el itinerario de investigación de Paulo Freire: contribuciones para la salud. Texto Contexto Enferm[Internet]. 2017[cited 2017 Nov 24];26(4):1-8. Available from: http://www.scielo.br/pdf/tce/v26n4/en_0104-0707-tce-26-04-e0680017.pdf

9. Pinto AH, Lange C, Pastore AC, Llano PMP, Castro DP, Santos F. Functional capacity to perform activities of daily living among older persons living in rural areas registered in the Family Health Strategy. Ciênc Saúde Colet[Internet]. $2016[\mathrm{cited} 2017$ Nov 21];21(11):3545-55. Available from: http://www.scielo.br/pdf/csc/v21n11/en_1413-8123-csc-21-11-3545.pdf

10. Heidemann ITSB, Wosny AM, Boehs AE. Promoção da saúde na atenção básica: estudo baseado no método de Paulo Freire. Ciênc Saúde Colet[Internet]. 2014[cited 2017 Apr 8];19(8):3553-9. Available from: http://www.scielo.br/pdf/csc/v19n8/14138123-csc-19-08-03553.pdf

11. Carretta MB, Bettinelli LA, Erdmann AL, Higashi GDC, Santos JLG. Compreendendo o significado do ser idoso vivenciando sua autonomia na hospitalização. Rev Rene[Internet]. 2013[cited 2017 Jul 13];14(2):331- 40. Available from: http://saudepublica.bvs. br/pesquisa/resource/pt/bde-24479

12. Finger D, Gomes AM, Schroder JD, Germani ARM. Promoção da saúde e prevenção de doenças: idosos como protagonistas desta ação. Rev Enferm[Internet]. 2015[cited 2017 Apr 26];11(11):80-8. Available from: http://revistas.fw.uri.br/index.php/ revistadeenfermagem/article/view/1695

13. Ferreira OGL, Maciel SC, Costa SMG, Silva AO, Moreira MASP. Envelhecimento ativo e sua relação com a independência funcional. Texto Contexto Enferm[Internet]. 2012[cited 2017 Jun 23];21(3):513-8. Available from: http://www.scielo.br/pdf/tce/ v21n3/en_v21n3a04.pdf

14. Manke LS. A presença da cultura escrita no meio rural entre as décadas de 1920 e 1940: o caso de leitores assíduos. Cad Hist Educ[Internet]. 2015[cited 2017 Jul 2];14(2). Available from: http://www.seer.ufu.br/index.php/che/article/view/32542

15. Organização Mundial da Saúde-OMS. Conceito de saúde segundo a OMS/WHO[Internet]. 2016[cited 2017 Jul 5]. Available from: http://cemi.com.pt/2016/03/04/conceito-de-saude-segundo-oms-who/

16. Ciolac EG. Exercise training as a preventive tool for age-related disorders: a briefreview. Clinics[Internet]. 2013 [cited 2017 Jul 23];68(5):710-17. Available from: https://www.ncbi.nlm.nih.gov/pmc/articles/PMC3654306/ 
17. Braz IA, Zaia JE, Bittar CML. Percepção da qualidade de vida de idosas participantes e não participantes de um grupo de convivência da terceira idade de Catanduva (SP). Estud Interdiscip Envelhec[Internet]. 2015[cited 2017 Mar 29];20(2):583-96. Available from: http://www.seer.ufrgs.br/RevEnvelhecer/article/view/48261

18. Braga IB, Braga EB, Oliveira MCA, Guedes JD. A percepção do idoso sobre a saúde e qualidade de vida na Terceira idade. ID On Line[Internet]. 2015[cited 2018 Jan 30];26(9):211-222. Available from: https://idonline.emnuvens.com.br/id

19. Cobo CMS. The influence of institutionalization on the perception of autonomy and quality of life in old people. Rev Esc Enferm USP[Internet]. 2014[cited 2017 May 13];48(6):1013-9. Available from: http://www.scielo.br/pdf/reeusp/v48n6/0080-6234reeusp-48-06-1013.pdf

20. Silva AFG, Berbel AM. O benefício da dança sênior em relação ao equilíbrio e às atividades de vida diárias no idoso. ABCS Health Sci[Internet]. 2015[cited 2017 Jul 21];40(1):16-21. Available from: https://www.portalnepas.org.br/abcshs/article/view/698 